\title{
Seeing the Media Education from the Lens of Critical Discourse Analysis
}

\author{
Veronica Saragi ${ }^{1}$, Annisa Septiani ${ }^{2}$, and Jumiati ${ }^{3}$ \\ ${ }^{1}$ Applied Linguistics Center, Pekanbaru, Indonesia \\ ${ }^{2}$ Universitas Lancang Kuning, Pekanbaru, Indonesia \\ ${ }^{3}$ Universitas Muhammadiyah Sidenreng Rappang, Sulawesi, Indonesia \\ ve.nick.0627@gmail.com
}

\section{ARTICLE HISTORY \\ Received : 11 February 2020 \\ Revised : 25 February 2020 \\ Accepted : 26 February 2020}

\section{KEYWORDS}

Discourse Analysis

Critical Discourse Analysis (CDA)

Media Education

Mass Media

Critical Media Literacy

\begin{abstract}
This paper is about critical discourse analysis in education, particularly when media of information is involved. Students use mass media to know about the world, which in turn is used to help them to learn. They obtain any and all sorts of information from media. Although mass media can help the students to learn, mass media also has an adverse effect. For that, the students must know how to critically mass media, not merely by knowing but also applying the theory of critical practice, critical media literacy and critical discourse analysis (CDA) in the media education. Therefore, this paper introduces and explains how CDA can be a productive research platform for teaching literacy in critical media. Using library research and data collected from electronic research databases, this study showed the application the research of pedagogy based on critical media literacy. This study extended an 8-year review of CDA in educational context by shedding light on the relevant studies published in current times.
\end{abstract}

\section{Introduction}

Discourse Analysis is the term to learn how the language used in the text, context, or something that exist in our life. Discourse analysis has many fields of learning like critical discourse analysis, discourse in media, discourse in medicine, discourse in politic, discourse in crime, etc. Nevertheless, this paper focuses on critical discourse analysis that is about critical discourse analysis in media education. Human society nowadays is very intertwined to media (Hamuddin, 2015). Almost all of the social activities have a relationship with media, including in education (Derin et al., 2019). Although every society knows that media not only have a good effect on them, but it has an adverse effect too. As we know, media is growing fast and can influence society fast from an adult until the children.

According to Rogers (2005), "education researchers turned to discourse analysis as a way to make sense of the ways in which people make meaning in educational contexts." Moreover, mass media has been used in educational context for decades, but much more in frequency as the students learn about their subjects and their world from mass media. This is where critical discourse analysis can use. Media must be given scholar attention because of how fast it can influence individuals, communities and societies (Hamuddin et al., 2019). The society has to know critic the media that use or know the critic analyses about media, especially media in education. There is the specific skill that needs for interpretation the mediated text appropriately; it is where the sign of linguistic completely with visual code, auditory, video or hyper-textual (Yunira et al., 2019). However, there is another skill needed for challenging ideological representation which dominated by mass media, especially when they did legitimize cultural oppression. It is known as critical media literacy.

Media discourse is an interesting perspective for exploring, and it more interest when the objectivity is the main topic. Because the objectivity that influenced by the power and ideology of the elite or media itself. The world of press, however, is less the real world and more the judged world (Kress, 1990). Suffice to say, media blatantly influences our comprehension and our knowledge about our world when they use a particular language (Fairclough, 2013). In effect, the language that used not by nature because it is made by world perspective and the dominant ideology.

The purpose of this paper is to provide arguments about media education that have used. We must know how to criticise media in education because the principle of critical teaching is education system will fail the society only use media without critic the media and discusses the theory in media. Therefore, this paper will introduce and explain with a short basic of postmodernist theory. It shows that critical discourse analysis is the platform the productive research that can be used for teaching literacy in critical media because both of them have the purpose for encouraging empowerment to expose danger ideology in public discourse. These arguments will thoroughly review two teaching models base on critical discourse analysis information suitable for critical media literacy. 


\section{Literature Review}

\subsection{The Theory of Critical Practice}

The critical practice is the kind of critical media literacy that cannot separate. It can be discussed in the context critical to political, social, and educational study. According to Foucault $(1972 ; 1977)$ and Habermas $(1979$; 1984) have changed our comprehension of how to the social function in post-industrial. They have challenged the argument of the individual that coherent, objective knowledge as neutral media to describe action and institution. Critical Theory, since the mid 20 century, was developed by educationalist. Academia is about the issue in the public that has the purpose of giving the knowledge and naturalization of social practice. Now, this issue cannot include exploration because there are modern technologies, communication and mass media.

Some postmodernist's think almost same with Theodor Adorno, they think pessimist with the mass media, that make the mass media that has been responsible for the environment. Because mass media can make social public is losing. However, there is an alternative approach towards the transformation of the public in postmodern that optimise with mass media. According to David Buckingham, losing of traditional bonds that possible the new technology did not create much instability in public. The public has diversified and not destroyed. Mass media that possible to develop the value, lifestyle and social that changed the ideology that has been happened for long.

Importantly, social justice and liberation of society that exists in the conclusion of theorist and then for awareness and empowerment that more critique through critical ideology or discourse deconstruction. According to a neoMarxist perspective, the social group that domination tended to adopt 'false consciousness'. They underestimate the institution and social structure that oppressive them. Critical ideologies make an explicit dangerous effect and guide the action daily of people and possible for them to confirm their attitudes. For example, the dominant individualism ideology in western society has believed that success depends on the quality and responsibility of each individual so that hiding the consequence of the unequal resource. This ideology has been disseminated effectively by mass media.

The term of critique or critical practice not linked with complaining and punishment. Critical is understood as an interrogation system to social categories and practice of discursive that considered reasonable and cannot be denied even though ideologies often motivate them. Involve in critical practice possible someone to give the question like "why do I believe with this idea or use this knowledge?" or "which is interest in my knowledge or support it?" (Mac Naughton, 2005:11). In this point, discourse studies do critical practice as one of the ways to explore how to people conceptualize thought the language that uses habitually. In here, the practice of critical discourse analysis has been a great purpose to identify the strategies of discursive that make the dangerous ideology not detected in public communication and expose the practice of 'exclusionary' like racism, sexism or xenophobia.

Indeed, critical discourse analysis has made contribution for the mass communication study by extensive textual analysis of various ideology factors in different sociocultural contexts. Similarly, In critical discourse analysis orientation research about media discourse, the term of critical was not used its weakness that referring to find obscurity arguments or less understanding in media message but this is a strength the critical politic committed (Wallace, 2003). Strength definition referring to identify, how media create the ideology, How they reproduce the dominant discourse, and how to share the knowledge. It is also essential for critical literacy teaching.

There is no claim that educational institution must be involved in critical practice, for example, through the critical reading course. Critical reading can be the right characters like show ideology representation to make the students be release with discursive practice. Nevertheless, in the teaching media literacy is essential to know to differentiate between developing critical media and media cynicism. Cynicism implies refusal the idea that the media text need to involve with what they represent. Cynicism said in popular clichés that all of the news is propaganda, all politics is the liar and all advertisement only cheat us. Otherwise, the criticism they believe that not representation in media.

\subsection{The Pedagogy of Critical Media Literacy}

Critical media literacy is a paradigm of pedagogy encourage the students understanding about literacy practice (how to result/received) the students in their sociocultural environment and often continue with the mass media text. The same purposes are often articulated by critical discourse analysis practice in expose hidden ideology in public discourse.

According to Kenneth Burke (1935), Every people is critical: every people must know the way to make assessment and evaluation criticism to respond the other people activities. Likewise, some discourse analysis admitted that there is critical instinct tend is worked in their experience of interpersonal communication in a social context. However, communication mediated by mass in contemporary societies can disturb the human ability to process the information critically. Take the example from contemporary broadcasting; there is the imbalance that is resulted, cognitive and emotional. This factor makes the difficulties in analysing to look at the cause and effect without oversimplification. Focus on efficiency and process information automaticity, the way of reading that not reflective and not critics did not like. 
Since the 1970s, critical discourse analysis has published the profound empirical studies that show the aspect of ideologies in public discourse. They have shown that the society saturated with media, process to maintain the power of relationship have changed from explicit propaganda to implicit convention of discursive and use the language that makes sense in public. For example, according to Fowler (1991) and Fairclough, they show this routine has develop be conversational, informal and orientation the client and have changed hierarchical practice. At first, that is praised as the practice of communicative that more fair and democratic. Nevertheless, many discourse analyses show their concern that practice base on media can allow controlling it more implicit ways. Now, this worry can be felt by the people about how to work in politic, media or advertisement. It seems critical that instinct is claimed needed to develop modern media dominate that.

According to Wodak \& Chilton (2016), take the critical perspective same with an emancipatory mission that declared by Critical discourse analysis that has formed for individual liberation. As a result, critical discourse analysis research that is wide can consult in setting the process and education material that purpose for boosting the critical media literacy. One of the steps to critical literacy have to increase the realize about dominant practice ideology discursive. For example, there are problems with the representations related to political, economic and social in various simple and complex frameworks. To increase discursive attention toward these issues, mass media often uses human sensations to intensify the conflict and cause hysteria. Thus, this study feels the need to know how to choose the media about text source linguistics.

It seems many categories of critical discourse analysis that borrow from grammar systematic Halliday and can use with pedagogy or teaching for help to increase critical literacy to students and society. For example, take attention in additional function, interpersonal, and textual from discourse and consideration on the text, period and mode of linguistics that form the organization and can be a practical framework for analysing the students. Critical discourse analysis shown how to discourse of society was read by ideology, not only linguistically but also graphically. The point that critical media literacy education should not use the methodology and the research offer the possible analyse about semiotic code and convention that exist in mass media modern.

Critical media literacy cannot understand as replication of students against critical discourse analysis research that completely. It is a demanding programme, and intuitive that resulted from critical practise that exists in the education context. In this environment, the critical practice can bring the illuminating result, mainly because of collective character and classroom interaction.

\section{Method}

This study aims to review the media education using the critical discourse analysis (CDA) perspective. To reach the objective, this study used the library research method to collect the data of relevant studies from databases of published articles and books, which are Google Scholar, Elsevier, Emerald Insight, and Taylor \& Francis. Figure 2.1 showcases the method of this current study.

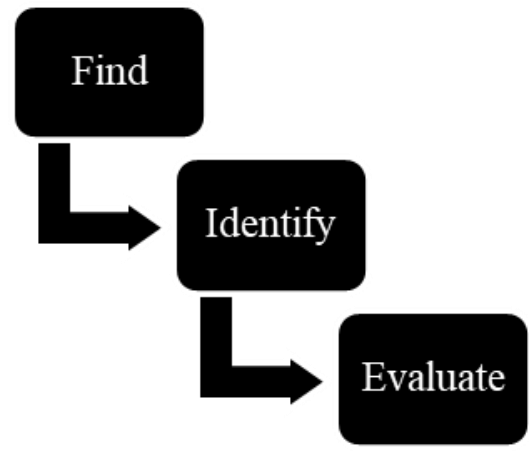

Figure 2.1 Methodological Framework

This study first tried to find studies on critical discourse analysis on educational context, then identifying ones that are especially related to media, whether they are written such as books or news, or audio-visual such as videos on social media. The researchers limited the search and literature review on studies that truly discussed critical discourse analysis, rather than merely mentioning it. While there was no strict coding selection beyond keyword-based search on the databases, the library research was conducted and cross-checked by every author to ensure the results and discussion align.

The researchers then evaluated the studies extracted from the electronic research databases individually then gathered to pool in the multiple interpretations and insights on the studies that have been found. Finally, the study applied the different results and focuses of these studies in the context of education to obtain an insight on media education from the lens of critical discourse analysis.

\section{Results \& Discussion}

This study used library research on electronic research databases to search for studies on critical discourse analysis in the context of education. One study extensively reviewed 257 articles of discourse analysis in education from 2004 to 2012 (Rogers et al., 2016). Other than the fact that the production of research in educational literacy remains the largest discipline and increased by sixfold in eight years, Rogers et al. (2016) also discovered that the clustering of the studies being from United Kingdom, United States, Australia, and Canada is reflective of the geopolitics of research publication. 
When it comes to critical discourse analysis in educational context, approximately $40 \%$ of the studies published from 2004 to 2012 took place in university settings, and there is actually a decrease in the use of middle and high school settings. It also seems that the focus on cultural diversity remains consistent, but the focus on gender and sexualities decreased around this time period. While not a direct cause, this may be due to the critical discourse analysis enduring heavy criticism by the academic community.

The criticism stems two things regarding critical discourse analysis in practice. The first is CDA's apparent language bias, as $64 \%$ of the studies were found to have focused primarily on written texts which are treated as passive objects to be studied. The second is CDA's apparent dependence on social theory and small inclination to concrete methods, which is particularly reflected by how 30 -years of CDA practitioners primarily only analysing 20 or fewer participants. However, it is also highly obvious that overtime, CDA practitioners reconstruct scholarship and learning as the discipline continues to answer the call of conducting more analysis on the intricacies of classroom talks and literate identities among communities (Rogers et al., 2016).

Seeing the progression of trends from the first decade of the twentieth century, this current study contributes to the body of knowledge by reviewing more recent related literature.

\subsection{Critical Discourse Analysis in Current Educational Context}

Considering the global tension when it comes to current politics, there are some critical discourse analysis studies focused on these issues. Ford (2017) presented the dissonance between global security discourse and school students' insecurity in Pakistan. The study explored whether securitisation engenders security or insecurity and interestingly found that securitised education is actually set to transform extremist mindsets to educated mindsets. However, education becomes ironically weaponised to transform students into soldiers that fight against extremism. Another study focused on online student activist movement that exposes everyday racism against Black people who are attending higher educational institutions (Mwangi et al., 2018). While not a new phenomenon by any stretch, it is surprising that there is little empirical scholarship on how discriminated groups face multiple forms of negative campus racial microaggressions. There are also recent studies similar to Zhao et al. (2018) that shed light on the refugee crisis. This study in particular focused on how Mexican, Central American, and Syrian im(migrants) and refugees are misrepresented in United States mainstream media, influencing the opinions of students and the masses.

Quite many studies found in this study focused on the gender discourse. Ezer, Jones, Fisher, \& Power (2019) recently examined the Australian curriculum, focusing on the sexuality education component within the documents and teacher roles. Like most studies, the CDA study found that the existing approach is still dominantly teacherfacilitated approach, which is a progress from initial teacher-centred approaches. With a much more personal approach, Parson (2019) identified the linguistic tools used in people's responses toward the author's previous article on gendered discourse. The study's analysis suggested trolling strategies were prominent in the corpus used to silence the author. With critical discourse analysis, the study states that this is proof of academics' opposition to feminist works (Parson, 2019).

\subsection{Critical Language Awareness}

Almost all of the discourse analysis explores the discourse media do not have a priority of pedagogy or teaching. Their finding and knowledge keep on their community-academic and rarely shared in public, including the educators, curriculum designer, and school administrator. Some critical discourse analysis projects imply direct education. For that Norman Fairclough's (1992, 2001), Critical language awareness (CLA) in English education must get the examination. Although CLA Fairclough imagines traditional reformation approach against the ability when reading the alphabet. However, it can be admitted as the steps to critical media literacy. Fairclough said that critical literacy awareness is the facilitator for emancipatory discourse that challenging and breaking the convention as an individual and collective struggle. He looked the education literacy as catalysts for increasing the awareness to oppression the ideology that realization through agreement, mainly in language that used in dominant orders of discourse, like public institution and media.

Fairclough (2001: 198-200) recommend the specific pedagogy or teaching guidance as a facilitator the critical language awareness: building the ability and language experience of students that have an understanding about how language work in the social context, and tide the awareness and practice implies the interprets. The purpose of discourse production is to develop the students' awareness of ideology effect in discourse. According to Fairclough's CLA, students or children must teach about the language that their use and preferably follow these steps. Firstly, they have to remember their experience in discourse practice and social context and then share in the class. Secondly, the teacher has to systematize the students experience with showing how to share their experience: introduction the language that their needs, arrange their reflection that systematic and giving the right and useful knowledge. Thirdly, the students can search the social explanation about the function and effect of discourse practice. Because awareness increasing, explanation before can be used to developing the purpose of discourse. For example, the students can reflect the style of headlines and caption of the picture on the newspaper, analyse and ambiguity identify that use linguistics category like 
prediction, agency, nominalization, and modality, discuss the function and impact from headline construction, study article and rewrite the headlines for reflecting the content of the text.

The other way to practice critical media literacy with CLA is encouraging the readers, listeners, and presenter in critical media and opposition. Although, the reader's opposition often assumed with experience or common knowledge in the classroom environment and students can try it. For example, the students can compare and know differentiate the interpretation of each other to the mass media text and imagine the alternative interpretation. They can try to speculate anything about the social effect of text and send the implicit intention and play a different role for a reason some message like different political, religious, economic and ethnic. It can help the students to know the subject position in the social text and to reevaluating their habits interpretation.

\subsection{The Pedagogy of Multiliteracies}

The critical discourse analysis framework for literacy that makes the group research England has submitted strong references against criticality, American, and Australian that know New London Group. The writer argues that the introduction the multiliteracy pedagogy or teaching allows the students to know critical literacy that is needed by them to creating their social future. This model of pedagogy or teaching remembers to the instruction of CLA Fairclough (2001) that are for reflected, systematized, explained and practised because of this move from the practice that exists to overt instruction so that the critical framework concludes transformed practice. However, it moves over critical attention against the pattern of language, because it emphasizes the multimodality including gestural, visual, aural and spatial literacy and the role of digital technology for produce the meaning in new media. For example, to interpret, analyse and evaluate the textbase the excellent internet, print the literacy, nonlinear, audio-visual and hypertextual to get the information.

The pedagogy of multiliteracy describes two crucial aspects from institutional, emerging cultural and global that exists: communication channels multiplicity and increasing the culture and language variation. Pedagogy of multiliteracy is different from approaching of traditional literacy, formal, monocultural, monolingual. The rule of the government focuses on representation in the outside of language. Modes of representation can be differently suitable for the cultural and situational context that has the cognitive effect and social. For example, mode verbal has gotten the privilege in education and scholarship.

\section{Conclusion}

This paper said that only media education with the critical component that can empower the individual indeed like critical discourse analysis. Critical media literacy is shown in the non-automatic and thoughtful way with the text and the reflection in the mediation context. The purpose media pedagogy is giving the students the necessary tools and category for deconstructing ideology implicit independently in the message of media. It involves the analysis of media text that relative to semiotics, visual code and other semiotics that they used, it followed by evaluation of representation dominant that they build. Criticism has to give attention to the publisher issues, production, and distribution and reception of media texts. Although critical media literacy can get in many situations through informal encounters with media and school, that must be the role in connected the critical aspect and creative of media literacy.

The vital component of media education is the way of teaching students about mass communication and media effect. It can increase the student's awareness, but it can cultivate cynicism than the healthy scepticism about mass media. Education focused only on exposing media manipulation maybe cannot bridge the gap between class and the students experience with media. As a replacement, bring the material for critical analysis in the study of the environment can be useful and interest. The education will claim that it only happens if media scientist and discourse related their research with practice. Their study will behave recommendation for action, and the action will make to understanding the pedagogy. This paper has shown the applying the research of pedagogy based on critical media literacy information on the media discourse can increase if they want to source of teaching and get the useful resource.

\section{Acknowledgement}

The researchers thank their friends and colleagues from U-RAISE Academy, Applied Linguistics Center, and Institute of Research and Community Service (LPPM) Unilak for their support during the discussions during the completion of this article.

\section{References}

Buckingham, D. (2005). Schooling the digital generation: Popular culture, new media and the future of education. London: University of London Press.

Derin, T., Deliani, S., Fauziah, N., Afifah, N., \& Hamuddin, B. (2019). Indonesians' Tendency to Refer Abbreviation as Acronym: Types of Abbreviation as Word Formation Process. Globish: An EnglishIndonesian Journal for English, Education, and Culture, 8(2).

Ezer, P., Jones, T., Fisher, C., \& Power, J. (2019). A critical discourse analysis of sexuality education in the Australian curriculum. Sex Education, 19(5), 551567.

Fairclough, N. (1992). Critical Language Awareness. Harlow: Longman 
Fairclough, N. (1995). Critical Discourse Analysis: Papers in the critical study of language. Harlow: Longman.

Fairclough, N. (2013). Critical discourse analysis: The critical study of language. Routledge.

Ford, K. (2017). The insecurities of weaponised education: a critical discourse analysis of the securitised education discourse in North-West Pakistan. Conflict, Security \& Development, 17(2), 117-139.

Foucault, M. (1972). The archaeology of knowledge. London: Tavistock.

Foucault, M. (1977). Discipline and punish. Harmondsworth: Penguin

George Mwangi, C. A., Bettencourt, G. M., \& Malaney, V. K. (2018). Collegians creating (counter) space online: A critical discourse analysis of the I, Too, Am social media movement. Journal of Diversity in Higher Education, 11(2), 146.

Habermas, J. (1984).The theory of communicative action (vol. 1): Reason and the rationalization of society. Cambridge: Polity Press.

Habermas, J. (1987). The theory of communicative action (vol. 2): Lifeworld and system. Boston: Beacon Press.

Hamuddin, B. (2015). Discourse on media: bringing hot news into ELT's classroom discussion. ISELT Vol.3

Hamuddin, B., Syahdan, S., Rahman, F., Rianita, D., \& Derin, T. (2019). Do They Truly Intend to Harm Their Friends?: The Motives Beyond Cyberbullying among University Students. International Journal of Cyber Behavior, Psychology and Learning (IJCBPL), 9(4), 32-44.

Kress, G. (1990). Critical discourse analysis. Annual review of applied linguistics, 11, 84-99.

Mac Naughton, G. (2005). Doing Foucault in early childhood studies: Applying poststructural ideas. London: Routledge.

Parson, L. (2019). Digital media responses to a feminist scholarly article: a critical discourse analysis. Feminist Media Studies, 19(4), 576-592.

Rogers, R., Malancharuvil-Berkes, E., Mosley, M., Hui, D., \& Joseph, G. O. G. (2005). Critical discourse analysis in education: A review of the literature. Review of educational research,75(3), 365-416.

Rogers, R., Schaenen, I., Schott, C., O’Brien, K., TrigosCarrillo, L., Starkey, K., \& Chasteen, C. C. (2016). Critical discourse analysis in education: A review of the literature, 2004 to 2012. Review of Educational Research, 86(4), 1192-1226.
Wallace, C. (2003). Critical reading in language education. Basingstoke: Palgrave Macmillan.

Wodak, R. E., \& Chilton, P. A. (2016). A new Agenda in (Critical) Discourse Analysis:[Translation in Chinese].

Yunira, S., Pradina, S., Sumbayak, M., Putri, N. S., \& Derin, T. (2019). Re-Visits the Grand Theory of Geoffrey Leech: Seven Types of Meaning. REiLA: Journal of Research and Innovation in Language, 1(3), 95-100.

Zhao, M., Rodriguez, J., \& Monzó, L. D. (2019). Media Discourses that Normalize Colonial Relations: A Critical Discourse Analysis of (Im) migrants and Refugees. 